\title{
Camponeses, a verdade e a História da ditadura em São Paulo
}

\section{Clifford Andrew Welch*}

Resumo: Enquanto a História Social do Campo no Brasil do período após a Segunda Guerra Mundial ainda permanece obscura, os movimentos sociais e sindicais do campo insistiram na inclusão da experiência camponesa no relatório a ser produzido pela Comissão Nacional da Verdade (CNV). Envolvidos em diversas investigações conduzidas pelas comissões estaduais e de âmbito nacional, historiadores vêm contribuindo para ajudar a entender o período de 1946 a 1988. Neste artigo, contribuímos com dados da repressão no período e com uma narrativa analítica sobre as violações de direitos humanos geradas no campo no contexto do golpe no estado em São Paulo. Como exemplo, utilizamos os eventos ocorridos em março de 1964 em Ribeirão Preto, aplicando a diversidade de recursos disponibilizados pelo ofício do historiador e necessários para resgatar a história de grupos subalternos. Com uma abordagem detalhada, pretendemos demonstrar os desafios de produzir história no contexto da pressa das comissões de verdade para compor "casos emblemáticos" em um tempo curto.

Palavras-chaves: história social do campo; repressão; Ribeirão Preto.

Abstract: While the post-World War II social history of the Brazilian countryside has yet to be written, rural social and labor movements have taken advantage of the fiftieth anniversary of the 1964 coup d'etat to push for inclusion of the peasant experience in reports written by the National Truth Commission, which was appointed by Brazil's president to document human rights violations before, during and after the dictatorship. Involved in various state and national endeavors to document repression and other human rights violations in the countryside, historians have contributed to the construction of a framework for understanding the period 1946 to 1988. This article offers new information about the repression of the São Paulo state peasantry in the period and a case study the human rights violations that occurred as the coup unfolded in the rural areas of Ribeirão Preto, São Paulo. Utilizing a diverse array of historical tools, the analytical narrative of this case seeks to demonstrate the challenges of producing history in the context of the short schedules allotted truth commission to generate reports, leading them to select "emblematic" rather than representative cases.

Keywords: rural social history; repression; Ribeirão Preto.

* Departamento de História, Universidade Federal de São Paulo. O autor deseja agradecer a Larissa Rosa Corrêa o convite para elaborar este estudo para a Revista Mundos do Trabalho e ao CNPq pelo auxílio do Edital Universal para seu projeto 478600/2010-0, "História da Luta pela Terra no Estado de São Paulo". 


\section{Introdução}

Depois de meio século, historiadores estão começando a reconhecer o que milhares de camponeses brasileiros têm guardado na memória há décadas: os anos da ditadura foram amargos. Cerca de 30 milhões trabalhadores rurais foram expulsos do campo neste período, milhares tiveram seus direitos humanos violados, alguns até à morte. ${ }^{1}$ Muitos migraram para áreas urbanas, deixando para trás parentes amados e terras conquistadas, mas raramente compradas. De uma forma ou outra, suas vidas foram transformadas, e o país também, em uma transposição de pessoas celebrada pela ditadura como avanço da própria civilização brasileira. ${ }^{2}$

Ainda podemos contar nos dedos o número de historiadores que tratam com respeito esta parte fundamental da história contemporânea do Brasil. Não significa que alguns historiadores não se importassem com o tema da História Social do Campo, mas a preocupação deles tem sido tradicionalmente distante do tempo presente. O objeto mais típico tem sido a escravidão. Outros historiadores envolveram-se com outros temas, como a formação social nos períodos da Colônia, Império e da Primeira República, quando a zona rural predominava. Percebe-se certo crescimento no número de estudos históricos sobre "homens livres", "pobres agricultores livres", cangaceiros, colonato, campesinato, imigrantes rebeldes e rebeliões no campo em geral, especialmente sobre Canudos e Contestado.

Importante neste aspecto foi o grupo de pesquisadores que fundou o Centro de Pós-Graduação em Desenvolvimento Agrário (CPDA), originalmente sediado na Fundação Getúlio Vargas e, desde 1982, incorporado à Universidade Federal Rural do Rio de Janeiro. Liderado inicialmente pela historiadora Maria Yedda Linhares, com financiamento do Ministério da Agricultura e da Fundação Ford, o grupo engajou jovens historiadores, como os cariocas Ciro Flamarion Cardoso, Eulália Maria Lahmeyer Lobo, Francisco Carlos Teixeira da Silva e o mexicano Guillermo Palacios. ${ }^{3}$

1 Há um extenso debate sobre o tamanho do "êxodo rural," os motivos e as consequências da mudança desse movimento, o que vamos examinar adiante. Em 1987, Georges Martine estimou este número em 20 milhões de pessoas. Em 1994, os demógrafos José Alberto Magno de Carvalho e Fernando Fernandes estimaram um número maior, cerca de 32 milhões. Ver MARTINE, George. Êxodo rural, concentração urbana e fronteira agrícola. In: MARTINE, George; GARCIA, Ronaldo Coutinho; Os impactos sociais da modernização agrícola. São Paulo: Editora Caetes, 1987, p. 59-79; CARVALHO, José Alberto Magno; FERNANDES, Fernando. Estimativas dos saldos migratórios e taxas líquidas de migração das unidades da federação e grandes regiões do Brasil. Trabalho para discussão CEDEPLAR, UFMG, Belo Horizonte, 1996.

2 Durante o governo do general Emílio Garrastazu Médici (1969-1974) foi lançado o slogan "Os sem-terra do Nordeste para as terras sem gente da Amazônia" para estimular a "integração nacional” através do plano de desenvolvimento baseado em grandes migrações de camponeses. Entre 1960 e 1980, mais de 16 milhões de pessoas deixaram o campo na região Nordeste. No final dos anos 1970, quando a ocupação do Norte já havia se revelado um desastre para milhares de pessoas, a ditadura criou o Programa Nacional de Apoio às Migrações Internas. VAINER, Carlos B.; BRITO, Fausto, Migration and Migrants Shaping Contemporary Brazil. Trabalho apresentado no XXIV International Union for the Scientific Study of Population, Salvador, BA, 18-24 de agosto de 2001. Disponível em http://www.digaai.org/wp/pdfs/migrantsandmigration. pdfn. Acesso em 12 de fevereiro de 2014.

3 Entrevista com Maria Yedda Linhares em MORAES, José Geraldo Vinci de; REGO, José Marcio (orgs.). Conversas com historiadores brasileiros. São Paulo: Editora 34, 2002. Ver também, MOREIRA, Roberto José. Mobilizando as agendas em torno da pesquisa social em agricultura: o Programa CPDA, a PIPSA e o Pronex. Notas de apresentação na Sessão I. Instituições, redes e grupos de pesquisa: Mobilizando as agendas em torno da pesquisa social em agricultura do Seminário Comemorativo dos 30 Anos do CPDA. Rio de Janeiro, 28 de novembro de 2006. O estudo mais atual do grupo foi CASTRO, Ana Célia; NOGUEIRA, Antônio Carlos; SILVA, Francisco Carlos Teixeira da; BICUDO, José Pereira Wilken; MOURA, Margarida Maria; LINHARES, Maria Yedda Leite; DELGADO, Nelson Giordano e BESKOW, Paulo Roberto. Evolução recente e situação atual da agricultura brasileira: síntese das transformações. Brasília: BINAGRI Edições, 1979. 
O fenômeno das Ligas Camponesas, associadas com o político Francisco Julião, foi alvo de pesquisas intrigantes que alcançaram o período da ditadura. Mas entre os historiadores, somente Zilda lokoi arriscou-se a narrar a experiência dos trabalhadores rurais no contexto do período ditatorial em uma analise comparativa da influência da teologia da libertação nos campos de Peru e Brasil. ${ }^{4}$ Destacase também o artigo do antropólogo Mario Grynszpan publicado na excelente coletânea O Brasil republicano de Jorge Ferreira. ${ }^{5}$

Talvez, pelas características das áreas de conhecimento, os antropólogos, geógrafos e sociólogos tenham uma formação mais adequada à analise o tema do que outras disciplinas. Geografia e sociologia têm subáreas especializadas em problemas agrários. São áreas que enfatizam a atualidade, e parte da atualidade do Brasil no século XX foi a transformação da relação campo-cidade. A mais chocante das mudanças foi a demográfica. Entre 1960 e 1991, a percentagem da população rural caiu 30 pontos: em 1960, 67,3\% das pessoas residiam no campo e em 1991 apenas 37,3\% continuavam a morar nas áreas rurais. ${ }^{6}$ Como comentaram os sociólogos Carlos B. Vainer e Fausto Brito, "as massas rurais que tinham sido imóveis foram lançadas no curso migratório" no período pós-guerra mundial. Isso foi consequência de "mudanças profundas na sociedade, primeiro com a abertura de novas fronteiras agrícolas no campo", e os migrantes "eram decisivos em determinar o tempo e formato do processo de industrialização-urbana no Brasil”. 7 Em outras palavras, uma importante história estava acontecendo e passava despercebida pela maioria dos historiadores.

Além da questão demográfica, os especialistas das outras áreas apontam diversas preocupações que exigem a atenção dos historiadores e historiadoras. De fato, são eles, os cientistas sociais, que primordialmente ocupam este território acadêmico com seus conceitos, interpretações e "breves históricos". Para tentar também integrar neste debate o olhar do historiador, pretendo abordar aqui dois temas: 1) o estado da pesquisa sobre "a verdade" da repressão no campo; 2) os camponeses e o golpe em um município, como exemplo da complexidade da "verdade".

\section{As Comissões da Verdade}

A maioria da migração do campo para as cidades ocorreu depois da Segunda Guerra e as idas e voltas entre os dois mundos nunca tiveram fim, sendo que a capital

4 Sobre as ligas do Nordeste, ver MONTENEGRO, Antônio Torres. Ligas camponesas e sindicatos rurais em tempo de revolução. In: FERREIRA, Jorge; DELGADO, Lucília de Almeida Neves (orgs.). O tempo da experiência democrática (1945-1964). (O Brasil Republicano vol. 3) Rio de Janeiro: Editora Civilização Brasileira, 2003, p. 241-271. Mas, seu olhar para o tempo presente e o capítulo citado que comentam as ligas a partir dos anos 1980, são produtos do século atual. IOKOI, Zilda Marcia Gricoli. Igreja e camponeses: teologia da libertação e movimentos sociais no campo Brasil e Peru. São Paulo: Editora Hucitec, 1996.

5 GRYNSZPAN, Mario. A questão agrária no Brasil pós-1964 e o MST. In: FERREIRA, Jorge; REIS FILHO, Daniel Aarão (orgs.). O tempo da ditadura (O Brasil Republicano, vol. 4). Rio de Janeiros: Civilização Brasileira, 2007, p. 315-348. Notáveis sinais do novo interesse dos historiadores na história social do campo são a publicação, em 2009, da Coleção História Social do Campesinato do Brasil em 11 volumes pela Editora da UNESP, organizada pelos historiadores Márcia Motta e Paulo Zarth e pelo sociólogo Horácio Martins de Carvalho, e a monografia escrita pelo historiador estadunidense ROGERS, Thomas E., The Deepest Wounds: A Labor and Environmental History of Sugar in Northeast Brazil. Chapel Hill: University of North Carolina, 2010.

6 Ver Tabela 3 in MARTINE, George; McGRANAHAN, Gordon, G. Brazil's Early Urban Transition: What Can it Teach Urbanizing Countries? Londres: Human Settlements Group, 2010, p. 12. Disponível em http://pubs. iied.org/pdfs/10585IIED.pdf. Acesso em 12 de fevereiro de 2014.

7 VAINER e BRITO, Migration and Migrants, p. 21. 
de São Paulo, por exemplo, ainda se destaca como destino urbano preferido. ${ }^{8} \mathrm{~A}$ observação de João Pedro Stedile, um dos fundadores e coordenadores nacionais do MST, "A luta pela terra se dá no campo, mas se ganha nas cidades" é expressiva da complexidade da relação campo-cidade. No momento desse pronunciamento, em 1996, o MST era considerado uma das cinco instituições mais bem avaliadas pelo público. Com a população concentrada nas áreas urbanas, o MST calculava que só nas cidades seria possível construir apoio para reforma agrária. No campo, podia-se esperar apenas conflito, porque era lá que se concentrava a resistência contra reforma. ${ }^{9}$

A tendência dos estudiosos em privilegiar as experiências urbanas, bastante determinadas pelas condições atuais, quando de fato a maioria da população mora em cidades, também influenciou a formação recente das comissões da verdade. Por volta de 2012, com a proximidade do cinquentenário do golpe, em 2014, comissões estabelecidas nos níveis nacional e estadual, sem falar das comissões em municípios e até instituições como universidades, foram encarregadas de investigar os casos de violações dos direitos humanos do período da ditatura. Algumas, como a Comissão Nacional da Verdade, foram direcionadas a investigar períodos mais amplos, no caso, de 1946 a 1988. Sem explicitar a necessidade de incluir a analise da repressão no campo, a questão foi geralmente ignorada até os movimentos sociais e sindicais mobilizaram-se para insistir na inclusão dos camponeses, povos indígenas e quilombolas.

Em agosto de 2012, as organizações responsáveis pelo Encontro Unitário dos Trabalhadores, Trabalhadoras e Povos do Campo, das Águas e das Florestas, em Brasília, destacaram a necessidade de o Estado investigar as violações de direitos das populações atingidas pelos projetos de desenvolvimento implantados pela ditadura, bem como as consequências da retomada das políticas de modernização conservadora no século atual. Especificaram entre os compromissos de seus militantes

lutar pelo reconhecimento da responsabilidade do Estado sobre a morte e desaparecimento forçado de camponeses, bem como os direitos de reparação aos seus familiares, com a criação de uma comissão camponesa pela anistia, memória, verdade e justiça para incidir nos trabalhos da Comissão Especial sobre mortos e desaparecidos políticos, visando a inclusão de todos afetados pela repressão. ${ }^{10}$

De fato, a Comissão Nacional da Verdade ouviu o protesto e instituiu, em novembro de 2012, um grupo de trabalho "sobre violações de direitos humanos relacionadas à luta pela terra e contra populações indígenas por motivações políticas". ${ }^{11}$ Enquanto uma equipe coordenada pela psiquiatra paulistana Maria

8 Uma obra que presta bastante atenção à relação campo-cidade neste contexto é do historiador FONTES, Paulo. Um Nordeste em São Paulo: trabalhadores migrantes em São Miguel Paulista (1945-1966). Rio de Janeiro: Editora Fundação Getúlio Vargas, 2008.

9 Stédile citado em LINHARES, Maria Yedda; SILVA, Francisco Carlos Teixeira da. Terra prometida: uma história da questão agrária no Brasil. Rio de Janeiro: Editora Campus, 1999, p. 208; COLETTI, Claudinei. Ascensão e refluxo do MST da luta pela terra na década neoliberal. Ideias. vol. 9, n 1, p. 49-104, 2002.

10 Compromisso 11, "Declaração do Encontro Nacional Unitário de Trabalhadores e Trabalhadoras, Povos do Campo das Águas e das Florestas”, 22 de agosto de 2012. Unidade no Campo. Disponível em http://encontrounitario.wordpress.com/declaracao-do-encontro/. Acesso em 19 de fevereiro de 2014.

11 Resolução $n^{\circ}$ 5, Comissão Nacional da Verdade, de 5 novembro de 2012. Disponível em http://www.cnv. gov.br/images/pdf/resolucao_05_051112.pdf. Acesso 21 de fevereiro de 2014. 
Rita Kehl, membro da comissão, assumiu a responsabilidade pela composição de um capítulo do relatório final da CNV dedicado ao assunto, um novo grupo de trabalho foi formado. Demorou, contudo, até maio de 2013 para os movimentos organizarem sua comissão especial, que logo ficou conhecida como a Comissão Camponesa da Verdade. Coordenada pelo sociólogo Sérgio Sauer, financiada pela CNV e utilizando a sede nacional da CONTAG para suas reuniões, a comissão camponesa foi composta de mais de vinte pesquisadores, a maioria com históricos de apoio aos movimentos sociais ou sindicais. No grupo, foram envolvidos poucos historiadores. ${ }^{12}$

No decorrer das tarefas, apareceu um conflito estrutural e ideológico, contradições evidentes já nas orientações formais dos dois grupos. Para a comissão camponesa, as violações dos direitos humanos não se restringiram às "motivações políticas" ou ao período 1946 a 1988. Brutalmente atingidos na atualidade por mega-projetos no Rio Madeira (RO) e no Rio Xingu (PA), por exemplo, os camponeses e povos indígenas sentem na pele as ligações diretas entre violações de seus direitos humanos e interesses econômicos, bem como os impactos da continuidade das políticas desenvolvimentistas entre os governos militares e civis. Por outro lado, a CNV, com prazos estabelecidos em lei e preocupada com limites de tempo, orçamento e espaço, empurrou a comissão camponesa a enfatizar "casos emblemáticos" de "graves" violações de direitos humanos até 1988, em que a participação - ou comissão ou omissão - do Estado em crimes era documentada.

Em diversos estados a mesma dinâmica se repetiu, quando membros da comissão camponesa retornaram para suas sedes de trabalho e encontraram com sua comissão da verdade estadual ou institucional para realizar suas tarefas. Quando planejamos nossos projetos de pesquisa em História, pensamos em desenvolver uma relação dialética/dinâmica com um corpo de evidências - documentos, depoimentos, reportagens ou vozes (histórias orais) - que vão, de certa maneira, determinar os resultados. Mas, a pressão para resgatar casos "emblemáticos de graves violações de direitos humanos vinculados ao Estado no período 1946 a 1988" para sintetizar a demanda, teve o efeito de alterar significativamente o ofício do historiador, cobrando à área de conhecimento uma resposta mais aquém das Ciências Sociais, por iniciar-se com metas definidas. Invés de buscar a capacidade de explicação temporal de um evento, a busca começou com uma necessidade de acumular casos dramáticos, chocantes, discriminados pelo papel do Estado.

Podemos examinar a problemática do processo no estado de São Paulo para entender a relação entre a produção da História Social do Campo, levantando parte da memória do campesinato no contexto da ditadura, e a produção de um relatório para a Comissão da Verdade.

A frase norteadora, "casos emblemáticos de graves violações", chama atenção por, no mínimo, dois motivos. Primeiro, pela oportunidade que oferece para criar uma narrativa, uma história, que chama a atenção do público ao mesmo tempo em que revela verdades sobre a condição humana, principalmente de um grupo - como o campesinato - negligenciado pela mídia e a literatura. Acredito que essa é a importância do momento criado pelo $50^{\circ}$ aniversário do golpe de 1964, porque com ou sem a pressão das comissões, a pesquisa continuaria, mas

12 A participação de pesquisadores das duas reuniões realizadas na Brasília em 2013 é indicativa, mas não conclusiva, da inclusão de historiadores no projeto. Foram presentes em um ou ambos os encontros os historiadores Angelo Priori, Carlos Hugo Studart, Cléria Botêlho da Costa, Clifford Andrew Welch e Regina Coelly Fernandes Saraiva. A lista de contatos pelo correio eletrônico também incluiu o nome de Antônio Montenegro. De qualquer forma, uma minoria da comissão. 
o palco, não. Segundo, porque os conceitos "emblemático" e "grave” não são fáceis de definir.

Poderia concluir que qualquer violação à Declaração Universal dos Direitos Humanos da Organização das Nações Unidas (ONU), de 1948, referência fundamental para os trabalhos das comissões, é emblemática e grave. Mas, pela experiência com as comissões, parece que as violações contra o campesinato são tão comuns que o acúmulo torna-se estatística, afogando qualquer noção de "caso emblemático". Nesta enchente de casos, houve uma preocupação com a divisão de espaço nos relatórios das diversas comissões, aumentando a pressão para identificar os casos mais dramáticos, quer dizer, mais violentos. Para padronizar os casos, criou-se uma ficha e o desafio dos pesquisadores era a busca de documentação para preencher todos os campos. Naturalmente, estas pressões favoreceram os casos já pesquisados.

Nesta complexidade de motivos e possiblidades, alguns geralmente positivos para a produção de história, e outros negativos, optamos, no caso de São Paulo, encontrar o meio termo por meio de um levantamento da documentação que espera produzir uma base mais representativa na escolha de casos e violações emblemáticas sofridas pelos camponeses do estado entre 1946 e 1988. Com esforço, motivado pelo curto tempo de abertura do palco das memórias da repressão, uma equipe de pesquisadores, estudantes e companheiros de diversos cursos e programas de pós-graduação conseguiu levantar diversas fontes para acumular dados que ajudariam rascunhar a violência e conflito inerente ao processo de desenvolvimento rural paulista. Em 16 de dezembro, 2013, a radiografia resultante do levantamento foi apresentada pelo Grupo de Trabalho sobre Repressão no Campo numa audiência pública da Comissão da Verdade "Rubens Paiva" na Assembleia Legislativa do Estado de São Paulo (ALESP). ${ }^{13}$

A pesquisa contribuiu para mostrar certos padrões de violações e ajudou na elaboração de interpretações geográficas e históricas sobre o campesinato no contexto do golpe. Ajudou gerar dados para contextualizar a ditadura a opção do grupo em levantar dados para um período maior do que o definido pela comissão da verdade estadual. ${ }^{14}$ Como a comissão nacional, pesquisamos a do pós-Segunda Guerra Mundial até a Constituição Federal de 1988. Ao longo do período, foram apurados 465 eventos de violações, envolvendo mais de 300.000 camponeses. Embora as violações tenham ocorrido em todo território do estado, a grande maioria foi concentrada em três microrregiões (ver Prancha 1). Estas são:

13 Os membros do grupo foram Aline Dias Ferreira de Jesus (UNESP), Clifford Andrew Welch (UNIFESP), Diego Becker (UNIFESP), Elson Luiz Mattos (UNIFESP), Gabriel dos Santos Nascimento (UNIFESP), Gabriel da Silva Teixeira (UNICAMP), Kleber Trambaiolli (Secretária da Educação), Larissa Mies Bombardi (USP), Lucas Julião Evangelista (UNIFESP), Luciana Carvalho (USP), Osvaldo Aly Júnior (UNIARA), Patrícia Cerqueira dos Santos (Secretária da Educação), Paula Franco (UNIFESP), Pompeu Salgado Carneiro (s/a), Rosana Akemi Pafunda (UNESP), Tiago Egidio Cubas (UNESP) e Yamila Goldfarb (USP). O presidente da comissão "Rubens Paiva", criada em 26 de outubro de de 2011 pela resolução nº 36, é o deputado Adriano Diogo (PT) e seu coordenador, Ivan Seixas, do Centro da Memória da Resistência.

14 Segundo o projeto da resolução n 36 de 2011, a assembleia legislativa estabeleceu "a Comissão da Verdade do estado de São Paulo para apuração de graves violações dos Direitos Humanos durante o período de 1964 até 1985 ocorridas no território do estado de São Paulo" sendo que "entre 1964 e 1985, viveu sob uma Ditadura Civil-Militar que tirou os mais elementares direitos da cidadania, sequestrou, manteve em cárceres clandestinos, torturou, assassinou e ocultou cadáveres de seus opositores, e, com a forte censura que impôs, impediu o conhecimento completo destes fatos, que até hoje permanecem sem que tenham sido esclarecidos devidamente. Por isso, a sociedade vem lutando, por diversos meios, para que o Estado apure toda a verdade, abrangendo os fatos, as circunstâncias, o contexto e as responsabilidades." Estado de São Paulo. Projeto de Resolução n 36 de 2011 da Assembleia Legislativa. Disponível em http:// www.comissaodaverdade.org.br/sobre.php?id=3. Acesso em 24 de fevereiro de 2014. 
Prancha 1 - Violações dos direitos humanos no estado de São Paulo de 1946 a 1988

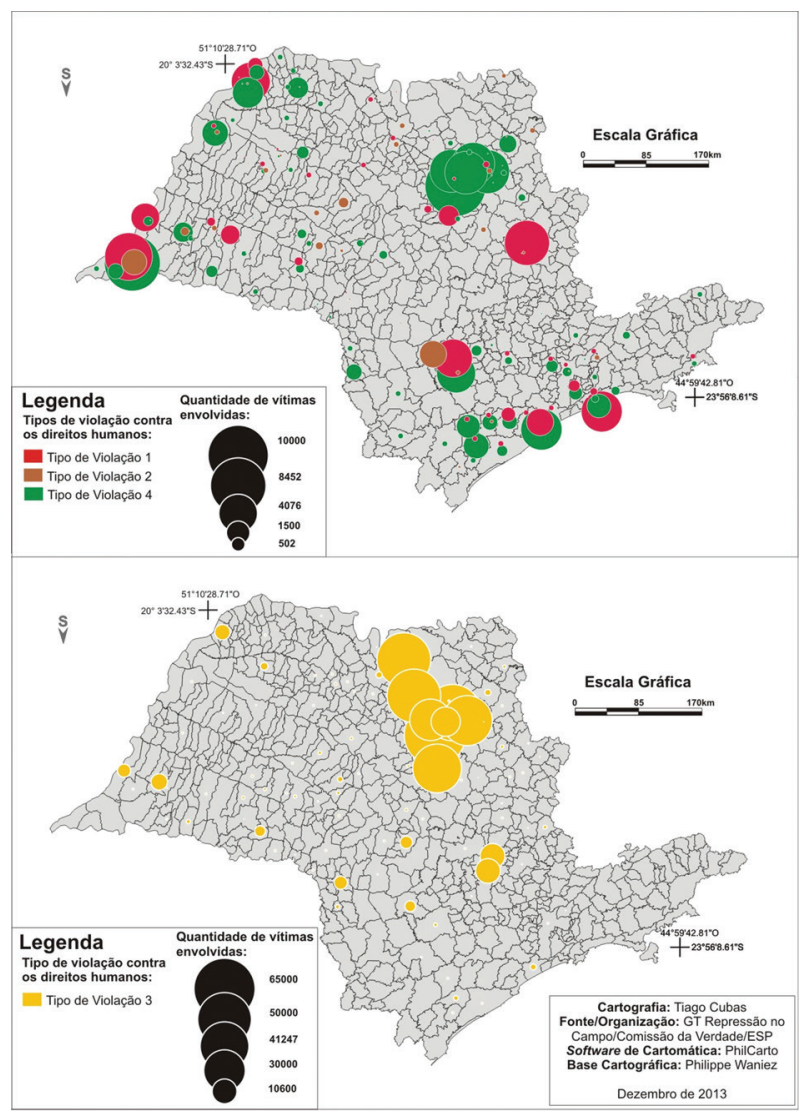

no litoral, com destaque para o vale do Rio Ribeira e o caminho da estrada RioSantos; no nordeste, com destaque para a Alta Mogiana, com sede em Ribeirão Preto; e na fronteira ao extremo oeste do estado, com destaque para o Pontal do Paranapanema.

Além de indicar as regiões das violações, os mapasforam organizados segundo as tipologias de violações. Ao critério de "grave" faltou abrangência suficiente para permitir a inclusão da variedade de violações encontradas em nossa pesquisa. Na pratica da CNV, "grave" veio a significar assassinato ou desaparecimento, mas no campo milhares de trabalhadores também sofreram violações sérias de seus direitos humanos na forma de trabalho escravo, superexploração (que também provocaria a morte), repressão de seus direitos políticos e de associação livre, bem como uma tendência brutal a interferir em sua vida privada, especialmente em seu direito à habitação e ao emprego, com a destruição de suas casas, lavouras e animais. Resolvemos levantar o sentido dos direitos humanos especificado na declaração universal, para desenvolver tipologias mais relevantes para analisar a experiência do campesinato paulista no período. A subdivisão de quatro tipos de violações ficou assim:

1) Violência contra a pessoa (ex. assassinato/ameaça de morte/ferimento/intimidação/tortura/desaparecimento);

2) Violação do direito à liberdade (ex. cassação/suspensão de direitos políticos/trabalho escravo/deslocamento forçado ou perigoso/migração enganosa/prisão);

3) Violação dos direitos trabalhistas (ex. associação livre para formar ou integrar em sindicato impedida/ 
superexploração sistemática - dívidas injustas - não pagamento - transporte precário ou perigoso);

4) Violação do direito a não interferência na vida privada, da sua família e no seu lar (Artigo XII - direito a habitação); a ser privado de seu bem estar (Art. XIII - liberdade de movimento/Art. XXIII - direito ao emprego - direito a salário justo) e de sua propriedade (Art. XXV - ex. despejo/expulsão das terras/destruição das lavouras, pertences/incêndios). (Ênfase nossa; artigos indicados são da declaração universal da ONU).

Nessa lista, o primeiro tipo foi reservado para os casos de graves violações, no sentido definido pelas comissões: assassinato, tortura, ferimentos corporais, desaparecimento resolvido ou não, ameaças sérias, tudo que for violência contra pessoas, violências geralmente praticadas pelo Estado ou classes dominantes para intimidar e reprimir ou eliminar indivíduos ou grupos, tais como militantes, sindicalistas e movimentos camponeses. Dada a natureza criminal deste tipo, a preocupação dos responsáveis foi garantir que tais atividades ficassem escondidas, o grupo desconfiou da sua capacidade e êxito em completar a tarefa, principalmente no período da ditadura. Consideramos o segundo tipo "grave," também, por ter como objetivo a exploração descontrolada do campesinato, ou pelo trabalho forçado ou pela repressão de sua capacidade se defender livremente.

A integração do tipo 3 permitiu a expressão de uma situação importante para entender a História Social do Campo. Na Prancha 1, no mapa abaixo, os casos do tipo 3 estão representados em separado dos outros tipos de violações, em parte por motivos visuais. Quer dizer, o número de camponeses que sofreram violações de seus direitos trabalhistas é tão maior que os outros tipos que sua inclusão necessariamente demandaria que fossem diminuídos os tamanhos das bolinhas de representação dos outros tipos, até o ponto de causar o desaparecimento dos casos menos numerosos mas não menos importantes, como as mortes do tipo 1.

O cálculo do tipo 3 foi especialmente importante para entender melhor a História Social do Campo no contexto da ditadura, porque um dos temas mais peculiares dos conflitos no campo era a situação legal dos camponeses, seus direitos trabalhistas e/ou a proteção da posse da terra. Em São Paulo, o golpe tinha o apoio da classe dominante, especialmente da elite rural. Intransigentes, eles se posicionavam contra os avanços dos camponeses frente aos conjuntos de leis do início dos anos 1960, como o Estatuto do Trabalhador Rural (ETR), SUPRA, CONTAG, a Revisão Agrária e a proposta de emenda constitucional para facilitar a comprar e redistribuição de terras sem função social. ${ }^{15}$

O quarto tipo definido, representado pela cor verde na Prancha 1, foi importante ser incluído no levantamento. Foram contemplados neste tipo as intervenções mais íntimas e perversas da História Social do Campo, que são as invasões nos lares e posses dos camponeses, derrubando suas casas, aterrorizando suas crianças, destruindo seus poucos pertences, quebrando seus instrumentos de trabalho, matando seus animais, queimando suas estruturas simples e ainda liquidando suas plantações. Se os "graves" casos estivessem limitados aos assassinatos, estaria perdida para a história uma categoria de violações que

15 WELCH, Cliff. Rivalidade e unificação: mobilizando os trabalhadores rurais em São Paulo na véspera do golpe de 1964. Projeto História. São Paulo, vol. 29, t. 2, p. 363-390, 2004. 
julgamos graves, não apenas pelas experiências brutais sofridas pelos camponeses, mas pela quantidade e amplitude da distribuição deste grupo de violações.

Nesse sentido, observa-se fundamentalmente uma luta feroz pela concentração da terra na região do estado de São Paulo durante todo o período. Em cada episódio de conflito, um fazendeiro ou empresário empregou seus jagunços para "limpar" terras geralmente devolutas, e assim griladas, expulsando os trabalhadores e trabalhadoras que já haviam feito todo o esforço para derrubar a mata e preparar o solo. No mínimo, essas ações deveriam ser consideradas um tipo de roubo. Mas, se a terra fosse interpretada como fonte principal da vida do campesinato, a expulsão dela deveria ser considerada equivalente a um massacre, uma vez que prejudicou o sustento não só de um indivíduo, mas geralmente de uma família inteira e até mesmo uma comunidade de famílias. Em nossa avaliação, violações do tipo 4 são até as mais importantes a serem resgatadas que os do tipo 1.

Figura 1 - Quantidade de vítimas envolvidas em tipos de violação aos direitos humanos no estado de São Paulo de 1946-1988
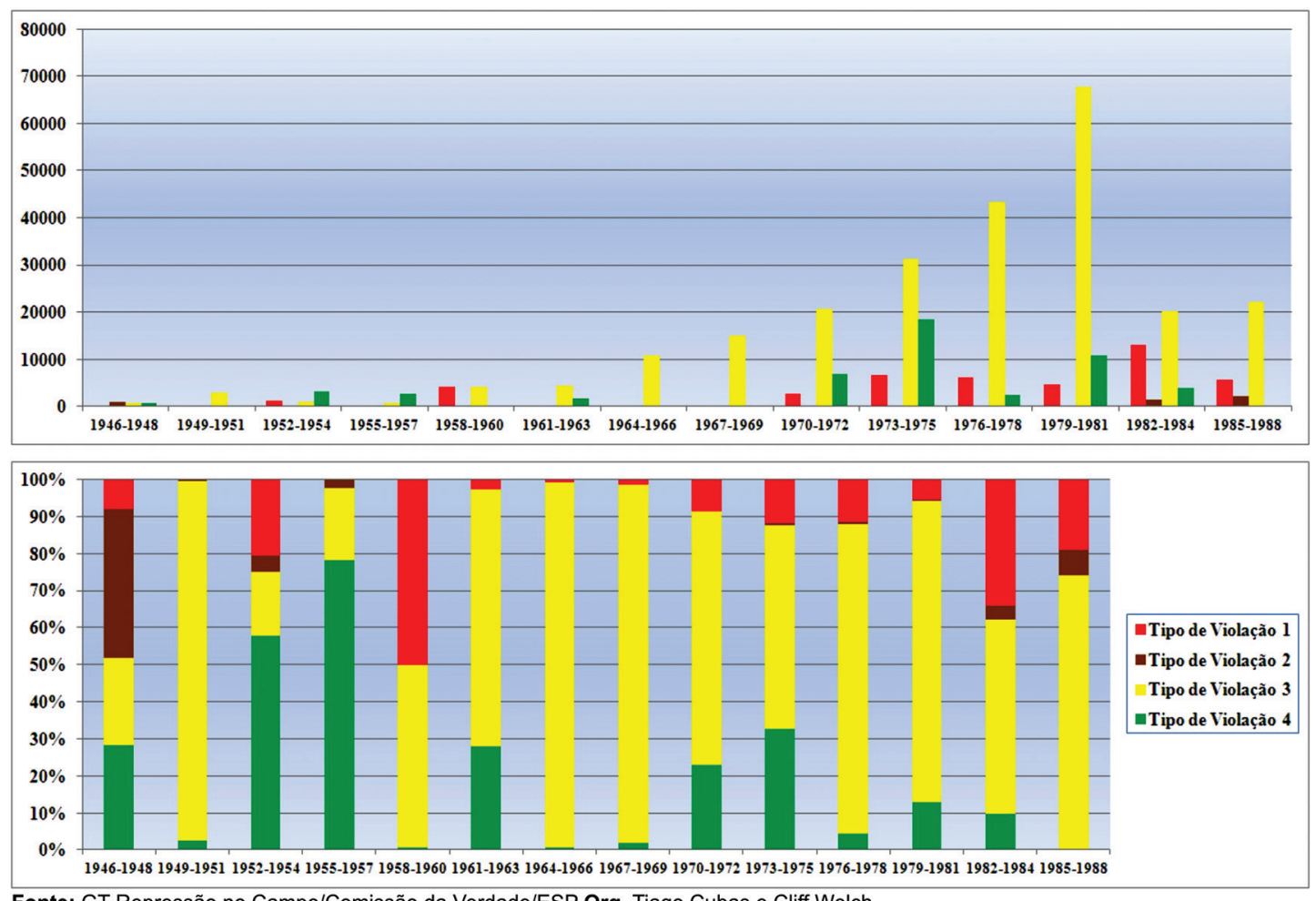

Fonte: GT Repressão no Campo/Comissão da Verdade/ESP Org. Tiago Cubas e Cliff Welch

A relação entre o número de vítimas dos quatro tipos de violações e o tempo é representada no gráfico de barras (ver Figura 1). Dividimos os 42 anos do período 1946 a 1988 em 14 blocos menores, de três anos cada, para tentar expressar o fluxo da relação. Utilizando as mesmas cores para cada tipo, a expressão dos dados em forma de barras consegue ser mais enfática com a predominância da cor amarela da importância das questões trabalhistas no campo no período.

O gráfico superior da Figura 1 mostra um crescimento dramático no número de violações no contexto da ditadura, especialmente nos anos da abertura, um resultado esperado da pesquisa, considerando os efeitos globais do movimento do "novo sindicalismo" da época. Associado à mobilização, encontramos um aumento também nas mais violentas violações, representado pela cor vermelha. Os altos e baixos índices mostrados pela cor verde expressam as violações dos direitos humanos a privacidade, emprego e moradia. Fatores que foram 
consequências dos mega-projetos orquestrados da ditadura. Entre eles estão a construção de barragens para a geração de energia nas novas usinas hidroelétricas e o Programa Nacional do Álcool (Pró-Álcool). O decreto que estabeleceu o PróAlcool é de 1975, e nos anos anteriores os fazendeiros e usineiros de São Paulo estavam já engajados no planejamento da política e construção de Complexos Agro-Industriais (CAls), protagonizando assim uma onda de concentração de terras para garantir a produção adequada de cana-de-açúcar para suas destilarias de etanol. "Concentração" é praticamente um eufemismo para a expulsão brutal dos camponeses de suas posses. O gráfico inferior da figura ajuda a visualizar a relação entre o número de vítimas dos quatro tipos de violações em cada bloco de três anos durante o período maior.

Tudo indica que a realização de novas pesquisas tenderia a aumentar essas estatísticas, especialmente no período da ditadura. Por um lado, de 1946 até o golpe, a imprensa alternativa de esquerda foi bastante animada e deu destaque à questão agrária e aos movimentos sociais do campo. O PCB, que foi quase hegemônico sobre os movimentos trabalhistas na cidade e no campo, publicou durante a maioria deste período um jornal - Terra Livre - dedicado à questão agrária e à organização dos trabalhadores rurais. Outros jornais comunistas, como Novos Rumos e Noticias de Hoje, deram atenção à violência dos latifundiários. Este período democrático também viu uma atenção maior às questões sociais nas publicações da classe dominante, como nas da Sociedade Rural Brasileira. A Igreja Católica e os líderes do Partido Trabalhista Brasileiro (PTB), institucionalizado por Getúlio Vargas, também deram destaque à situação rural em jornais como Diário de Noticias (Ribeirão Preto) e o Última Hora (Rio e São Paulo). São várias as pesquisas realizadas sobre a época no estado de São Paulo. ${ }^{16}$

Por outro lado, até agora, são poucas as pesquisas históricas realizadas sobre a questão no contexto da ditadura. ${ }^{17} \mathrm{~A}$ fragmentação das esquerdas, a repressão e a censura à imprensa dificultam a pesquisa da História Social do Campo desta época. A disponibilidade de documentos oficias, especialmente judiciais, ainda é mais limitada para o período da ditadura, devido a questões políticas e sua proximidade temporal. Nestas circunstâncias, a única vantagem da ditadura sobre o período anterior é sua pujança para a história oral, considerando a mortalidade de quem já era adulto antes do golpe.

Apesar das limitações da pesquisa, foi possível confirmar uma significativa intensificação dos conflitos no campo paulista durante a ditadura. A Prancha 2 destaca a localização e o número de violações em três períodos históricos entre 1946 e 1988 (as violações das leis trabalhistas foram excluídas para permitir uma melhor visualização dos demais tipos). Fica ainda mais evidente neste recorte dos dados levantados um crescimento dramático nas violações aos direitos humanos dos camponeses nos anos da ditadura. Assim a opção política da Comissão Nacional da Verdade de levantar dados sobre um período maior que a ditadura - 1946 a 1988 - acaba por confirmar o senso

16 Duas fontes básicas são a coleção de resumos da imprensa anarquista, socialista e comunista em BARRIGUELLI, José Cláudio (org.). Subsídios à história das lutas no campo em São Paulo (1870-1956), 3 vols., São Carlos, SP: Arquivo de História Contemporânea/UFSCar, 1981; e WELCH, Clifford Andrew. A semente foi plantada: as raízes paulistas do movimento sindical camponês, 1924-1964. São Paulo: Expressão Popular, 2010.

17 Até agora, para o estado de São Paulo, a fonte básica é BASTOS, Elide Rugai; CHAIA, Vera; FERRANTE, Vera Lúcia Botta. As lutas sociais no campo no estado de São Paulo - 1964 a 1981 - Relatório de pesquisa de 1982 a 1983. 3 vols., CEDIC/PUC-São Paulo. 1983. Outros estudos importantes do estado de cientistas sociais são: COLETTI, Claudinei. A estrutura sindical no campo: a propósito da organização dos assalariados rurais na região de Ribeirão Preto. Campinas: Editora da Unicamp, 1998; e FERNANDES, Bernardo Mançano. MST: formação e territorialização. São Paulo: Editora Hucitec, 1996. 
comum sobre a deterioração da situação dos trabalhadores rurais e seus direitos sob o governo autoritário dos militares e seus aliados na burguesia.

Prancha 2 - Violações 1, 2 e 4 aos direitos humanos por períodos de 1946 a 1988

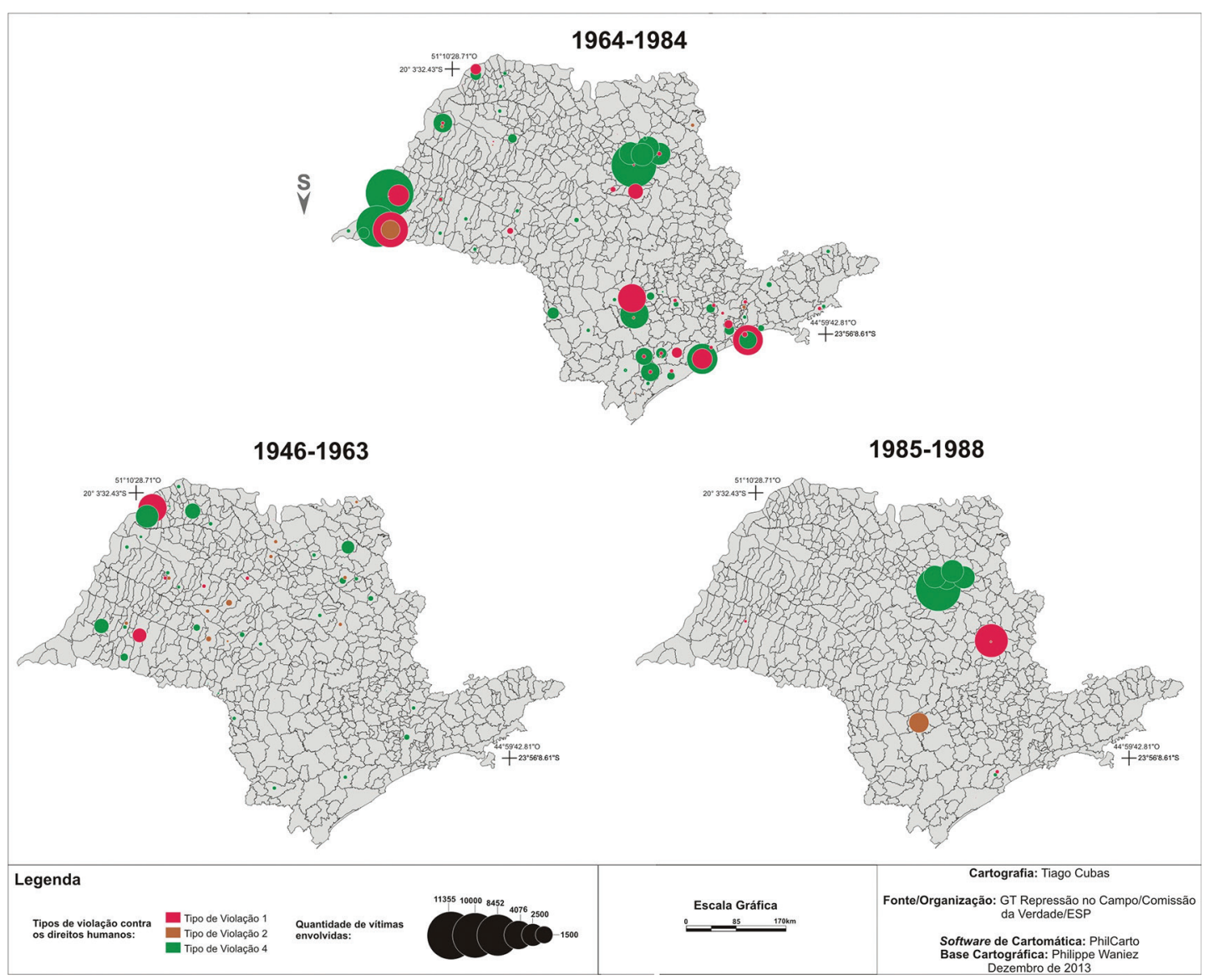

Ainda examinando a Prancha 2, é possível identificar um claro vínculo entre as frentes de "modernização conservadora" em São Paulo e o crescimento das violações. O conceito de "modernização conservadora", desenvolvido pelo sociólogo Barrington Moore, foi aplicado ao modelo de desenvolvimento econômico implementado pela ditadura, especialmente no campo, onde a combinação entre o regime militar, a burguesia e os terratenentes funcionou para reforçar o controle da oligarquia rural sobre os camponeses, trabalhadores rurais ou pequenos agricultores familiares. ${ }^{18}$ Como foi indicado na discussão da Figura 1, o "outro lado" dos mega projetos do período foi o sofrimento causado a milhares de pessoas pelo êxodo rural. Pelas próprias manchas no mapa, é possível reconhecer a relação entre a repressão e a construção de barragens na região do Pontal do Paranapanema e no Rio Paraná, a concentração de terras e industrialização nos CAls do Pró-Álcool na bacia da Mogiana em volta de Ribeirão Preto e a luta pela terra provocada pela construção da estrada Rio-Santos e a valorização imobiliária do litoral paulista.

18 PIRES, Murilo José de Souza Pires; RAMOS, Pedro. O termo modernização conservadora: sua origem e utilização no Brasil. REN - Revista Econômica do Nordeste, vol. 40, n 3, p. 411-24, 2009. 


\section{O golpe e o movimento camponês em Ribeirão Preto}

A Prancha 2 mostra-se especialmente clara ao indicar a distinção da microrregião de Ribeirão Preto como foco de luta durante a ditadura. Na divisão dos dados utilizados na produção da prancha, os três meses que antecederam o golpe, foram incluídos no mapa do meio que representa o período da ditadura. Tomando como exemplo agora somente o mês de transição política do período - março de 1964 -, podemos considerar as complicações da busca da "verdade" sobre as violações de direitos humanos no campo atualmente e assim avaliar alguns problemas produzidos por pesquisas guiadas pela busca rápida de "casos emblemáticos". Depois do famoso discurso proferido pelo presidente João Goulart durante uma assembleia realizada no Rio de Janeiro no dia 13 de março, a história de Ribeirão Preto pode contribuir para ilustrar como a luta entre os grupos de apoio e oposição das reformas de base intensificou-se, especialmente no tocante à reforma agrária. ${ }^{19}$

Uma oportunidade para analisar em detalhe o conflito surge no contexto de um curso de treinamento que os líderes dos movimentos camponeses da região haviam pedido que a Superintendência da Política Agraria (SUPRA) organizasse. Goulart criou a SUPRA no final de 1962 para fomentar, implantar e administrar os projetos que visavam a transformação socioeconômica do campo. Como parte do plano, o governo começou a reconhecer oficialmente os sindicatos dos trabalhadores rurais. A SUPRA encarregou-se de capacitar os organizadores e administradores destas novas entidades institucionais. ${ }^{20}$

No dia 17 de março, o coordenador da SUPRA em Ribeirão Preto, o agrônomo Hans Alfred Rappel, foi ao quartel-general do órgão, na capital do estado, com o objetivo de receber a verba requisitada para realização dos cursos de formação sindical. Voltou a Ribeirão Preto levando $\mathrm{Cr} \$ 700.000,00$ e entregou a Irineu Luís de Moraes Cr\$270.000,00 (cerca de US\$150) para cobrir os custos do encontro. Moraes era um militante do PCB na região, desde os anos 1930, dedicado à mobilização dos camponeses. A partir de dezembro de 1963, Moraes estava associado à CONTAG - Confederação Nacional dos Trabalhadores na Agricultura, então estabelecida pelo Estatuto do Trabalhador Rural (ETR).

Preocupado com a manifestação da oposição no dia 19 de março - a famosa marcha "Da família com Deus pela liberdade" em São Paulo - Mario Donato, o diretor estadual da SUPRA, tentou encontrar Rappel naquela noite para fazer um pedido urgente. Donato queria expressar seu desejo de suspender as aulas de treinamento para evitar maiores polêmicas até que a crise passasse. Porém, não conseguiu conversar com Rappel e teve que enviar uma mensagem através de uma secretária. Rappel, que recebeu a mensagem no dia 20 de março, enviou um telegrama indicando que era tarde demais para cancelar. A sessão de treinamento já estava marcada para os dias 21 e 22 de março. Além disso, escreveu, a manifestação não tinha tido maiores consequências na região. Tudo estava calmo, assegurou a seu chefe. ${ }^{21}$

19 FERREIRA, Jorge, João Goulart. Uma biografia. Rio de Janeiro: Civilização Brasileira, 2011.

20 WELCH. A semente foi plantada, p. 287-289.

21 Leitores em Ribeirão Preto seguiram os acontecimentos nacionais pelas primeiras páginas dos jornais com manchetes tais como "Será assinado no dia 13 de março próximo o decreto de desapropriações de terras". Diário das Noticias (doravante citado como DN, publicação da Arquidiocese da Igreja Católica em Ribeirão Preto), p. 1, 16 de fevereiro de 1964. 'Todas as atenções do país voltadas para o Rio com a realização do comício de reformas de base.' DN, p. 1, 13 de março de 1964. Os interrogadores da polícia extensivamente questionaram Rappel e sua assistente sobre a sessão de treinamento e a disputa com Donato. Esta afir- 
Em contraste com a prudência que Donato recomendava, o ritmo das atividades da SUPRA em Ribeirão Preto havia, na verdade, se intensificado. Enquanto voluntários ofereciam cursos sobre direitos trabalhistas e gestão sindical para líderes dos trabalhadores de toda a região, Rappel dirigiu-se a Altinópolis para registrar a formação de mais um sindicato rural. O dia mais importante para a SUPRA ainda estava por vir: na quinta feira, dia 24 de março, dezenas de pessoas participariam do primeiro encontro geral para organizar o escritório regional. Esperavam a participação de jornalistas, advogados, sacerdotes, líderes sindicais, estudantes de medicina e odontologia, além de dezenas de outros interessados na formação básica e mobilização política dos camponeses.

Aparentemente impassível frente aos eventos nacionais, o grupo planejou marcar a inauguração formal da SUPRA local para a ocasião da visita de João Goulart a Ribeirão Preto, prevista para o dia 12 de abril. Para financiar o grande encontro de camponeses que se esperava organizar em homenagem a Goulart, padre Celso Ibson de Syllos pediu a Rappel Cr\$2.500.000,00 (cerca de US\$ $1.400,00) .{ }^{22}$ Padre Celso foi líder da Frente Agrária Paulista (FAP), que ministrou cursos de "conscientização política" de camponeses e organizou sindicatos para defender seus interesses frente à classe patronal. Padre Celso representava a frente política progressista da Igreja Católica, que procurou contornar as tendências mais tradicionais da direita dentro da instituição, representadas no estado por José Rotta, líder dos Círculos Operários e logo identificado como aliado da conspiração contra o governo Goulart. ${ }^{23}$

Se, por um lado, o ritmo dos eventos nacionais parecia tanto acelerar como alterar a agenda da SUPRA, aqueles que apoiavam a conspiração contra o presidente apressaram simultaneamente suas atividades. Depois do sucesso da Marcha da Família, eles solidificaram seus planos e marcaram o golpe secretamente para o dia $1^{\circ}$ de abril. Com a tomada de poder pelos militares já preparada, os grupos civis receberam ordens para intensificar a pressão sobre as autoridades leais ao presidente. A situação chegou ao limite em Ribeirão Preto, assim como em outros lugares, no fim do mês de março. "Nas vésperas da revolução", o padre Celso nos falou, "já havia todo um trabalho da burguesia e dos fazendeiros de organizar um movimento contra a esquerda". 24

A primeira batalha ocorreu no sábado, dia 28 de março, no Colégio Maristas. Em um debate patrocinado pelo Movimento de Arregimentação Feminina (MAF), padre Celso enfrentou o inimigo. Para estimular um confronto, o MAF convidou o padre Masueto, um sacerdote conservador de São Paulo, para pôr na defensiva tanto padre Celso como seus aliados, incluindo o prefeito Wilson Gasparini, até então um aliado da FAP. Masueto acusou o padre Celso de ser um "assalariado de

mação foi feita com base nos testemunhos de Rappel e Di Salvi encontrados no processo da coleção Brasil Nunca Mais 2/144, Arquivo Edgard Leuenroth, UNICAMP (AEL).

22 Depoimento Rappel. B:NM 2/144, AEL. Vinte e oito ativistas do trabalho rural compareceram ao curso. Embora não haja registro de seus nomes, era possível determinar que pelo menos quatro dos presentes eram de Bonfim Paulista, três de Franca, quatro de Ituverava, quatro de São Joaquim da Barra, três de Pontal, três de Barrinha, cinco de Sertãozinho, e dois de Guatapará. Os recibos daqueles que fizeram a prestação de contas inclui o número de passagens para cada uma dessas cidades. Recibo das despesas do curso com os dirigentes sindicais da Alta Mogiana. B:NM 2/144; e O presidente da república viria dia doze de abril a Ribeirão Preto para inaugurar agência da SUPRA. DN p. 8. 25 de março de 1964. O planejamento para a visita de Goulart é discutido em Transcrição de Syllos, pp. 67-70; e depoimento Rappel. B:NM 2/144. A transcrição das entrevistas realizadas com Syllos pelo autor em janeiro de 1989 está disponível para consulta no AEL.

23 De fato, no pós-golpe, Rotta foi elevado pela ditadura como presidente-interventor da CONTAG. Veja MAYBURY-LEWIS, Biorn. The Politics of the Possible: The Brazilian Rural Workers' Trade Union Movement, 1964-1985. Philadelphia: Temple University Press, 1994.

24 Transcrição de Syllos, p. 70. 
Moscou" e provocou uma briga com o prefeito. O grupo de apoio que acompanhou Masueto não permitiu que Gasparini falasse, gritando "burro", empunhando bastões e atacando aqueles que tentaram defender o prefeito e padre Celso. O conflito só se encerrou com a chegada da polícia. ${ }^{25}$

As atividades religiosas do dia seguinte fizeram com que padre Celso esquecesse os eventos de sábado. Moraes, por outro lado, só ficou sabendo do ocorrido no domingo. Descansando em sua pequena casa nos arredores de Ribeirão Preto, Moraes lembra-se de ter escutado uma reportagem no rádio sobre o confronto no momento em que recebia um telegrama de São Paulo. A mensagem pedia para que ele participasse de uma reunião de emergência do comitê estadual do PCB na manhã do dia seguinte, dia 30 de março. Logo, Moraes saiu para a capital no carro do dr. Clarimundo Soares juntamente com outro membro do partido. Chegando a São Paulo, dirigiram-se à sede estadual do partido, que ficava no décimo quarto andar do Edifício Martinelli, disfarçada de "escritório eleitoral". Ao chegarem, o salão estava quase cheio, com dezenas de camaradas vindos de todos os cantos do estado. No entanto, o encontro mal havia começado, quando um jovem chegou gritando para avisar que a polícia estava se preparando para invadir o prédio. Como lembrou Moraes, todos desceram os 14 andares pela escada. Moisés Vinhas, intelectual e líder do PCB, advertiu a Moraes e Soares: "Façam estoque de gasolina, encham bastante o tambor de gasolina. Preparação!"”. ${ }^{26}$

Moraes lembra ter ficado muito irritado. Na última hora, o partido esperava que seus militantes revertessem anos de estratégia de acomodação. "Agora, até ontem vocês eram contra, agora mandam fazer estoque de gasolina. Aonde, de que jeito? De hoje para amanhã?" Considerando esse dilema no caminho de volta a Ribeirão Preto, decidiram falar com padre Celso. Moraes encontrou o padre no dia 31 de março e contou-lhe o que havia acontecido em São Paulo. Pela primeira vez, revelou que ele e cerca de trinta camponeses e outros militantes haviam participado de treinamento militar em uma fazenda perto de Altinópolis. Com um golpe militar acontecendo, Moraes pediu a cooperação do padre no planejamento da resistência. Se padre Celso usasse sua influência para preparar uma greve geral em Ribeirão Preto, Moraes e seu grupo guerrilheiro tentariam neutralizar a polícia nas cidades vizinhas. ${ }^{27}$

Padre Celso lembra que ficou surpreso com o que ouviu. Apesar de os jornais reacionários terem escandalizado os leitores ao mencionarem exércitos revolucionários de camponeses no interior do país, padre Celso havia ignorado o

25 Os incidentes de 28 de março estão reportados em O prefeito Welson Gasparini violentamente ofendido em reunião ontem à noite, sendo-lhe negada a palavra! DN. p. 8, 29 de março de 1964 e transcrição Syllos, p. 41-42. Vide Os acontecimentos lamentáveis de sábado: Exposição ampla do Prefeito Welson Gasparini. DN. p. 8, 31 de março de 1964.

26 Embora padre Celso continuasse a guiar a Frente Agrária, o arcebispo de Ribeirão Preto Ângelo Rossi tinha ordenado a direção da organização a um leigo, Duarte Nogueira, mais cedo no mesmo ano. Desde essa época, o padre tinha saído do escritório da Frente Agrária e voltado a morar na paróquia de Vila Seixas em Ribeirão Preto. Transcrição Syllos. p. 73; e O DN circulará a partir do dia $1^{\circ}$ de março pleno êxito nas gestões de domingo último. DN. 25 de fevereiro de 1964, p. 8. Sobre as atividades de Moraes, vide transcrição Moraes parte 1, p. 91-92; e MORAES e VIANA. Prestes, p. 177-181. Para a citação de Vinhas, vide transcrição Moraes parte 1, p. 92.

27 Para as revelações de Moraes sobre o campo de treinamento para a guerrilha, vide transcrição das entrevistas realizadas pelo autor com Moraes em 1988 parte 1, p. 65-66, p. 89-90, e parte 3, p. 32 (AEL). Mais sobre o campo pode ser encontrado em transcrição Antonio Girotto, p. 22 (AEL); e Arlindo Teixeira, transcrição da entrevista feita pelo autor, Ribeirão Preto, 18 de outubro de 1988, p. 22-23 (AEL). "Era besteira”, disse Teixeira sobre o campo. "Apenas serviu para nos prejudicar. Eu participei lá também. Mas era bobagem, completa porcaria". 
alarme, convencido de que, se tais exércitos existissem, eles seriam ineficazes. Afinal, o Brasil não era uma ilha das proporções de Cuba. Mas Moraes confirmou os relatos e, além disso, pediu que o padre ajudasse. Em vez de discutir as guerrilhas, padre Celso lembra-se de ter dito a Moraes que era ridículo achar possível organizar uma greve geral da noite para o dia. O movimento dos trabalhadores não era suficientemente coeso. Além disso, o apoio popular ao seu trabalho ainda era muito superficial. "O que devo fazer?" perguntou. "Começar um movimento no meio da manhã, quando todos estão dormindo, ou ouvindo quietos o rádio, em suas casas, assustados?" Mas o padre Celso ainda decidiu seguir seus princípios e publicar e distribuir um jornal opondo-se ao golpe. Com a guarda policial vigiando o jornal do lado de fora de seu escritório, ele e sua equipe imprimiram uma edição de oito páginas. Mas poucas cópias foram distribuídas antes que as autoridades descobrissem o esquema. $\mathrm{O}$ chefe de polícia deve ter ficado furioso ao ler as manchetes da primeira página: “LUTE PELA PAZ!" e “DECLARADA A GREVE GERAL!”.28

A edição de $1^{\circ}$ de abril foi a última editada por padre Celso. No início da manhã, o ataque, coordenado pela direita, de vários alvos estratégicos em toda a nação, havia cumprido sua função. Com mínima resistência, o golpe estava completo; João Goulart foi deposto em menos de dois dias. Em Ribeirão Preto, a polícia ocupou os escritórios do Diário de Notícias, impedindo que o jornal publicasse novas edições até o dia 12 de maio; a polícia fechou também o Diário da Manhã antes que sua edição de $1^{\circ}$ de abril fosse ao prelo, e não permitiu o reinício de sua publicação até o dia 31 de maio. No escritório do Diário de Notícias, a polícia apreendeu todas as cópias do jornal de fevereiro a março, não deixando nenhum vestígio do periódico desses meses críticos. ${ }^{29}$

O escritório da SUPRA também foi invadido, fechado, e sua equipe interrogada. Aqui, também, a polícia confiscou tudo. O novo regime usou os documentos apreendidos para desacreditar a agência e o movimento camponês na imprensa; promotores militares também utilizaram esses papéis para iniciar processos criminais contra a agência e seu pessoal. Todos os envolvidos foram acusados de subversão, de acordo com a Lei de Segurança Nacional. Por oito anos, o governo militar perseguiu Donato e o restante do grupo.

Em São Paulo, assim como em outros estados, a SUPRA foi selecionada como alvo privilegiado da repressão, pois tinha conseguido em um curto prazo de tempo apaziguar a rivalidade entre as diversas facções dedicadas a mobilizar os camponeses, ajudando-as a obter um nível nunca antes visto de unidade. Esse movimento cada vez mais consolidado ameaçava tornar-se cada vez mais poderoso e eficaz, intensificando a ansiedade da classe rural dominante. Se por um lado muitos acontecimentos levaram os proprietários de terra a se oporem ao regime de João Goulart, o potencial poder de unificação da SUPRA assustava-os de

28 Transcrição Syllos, p. 72; e DN, $1^{\circ}$ de abril de 1964, p. 1. Sobre a resistência armada, vale a pena lembrar a experiência do partido com a resistência dos posseiros de Porecatu, PR, e a dos colonos de Formoso e Trombas no Estado de Goiás. Segundo várias fontes vinculadas ao próprio partido, o PCB manteve um setor militar, o TE - Trabalho Especial, que ficou responsável por desenvolver a capacidade revolucionaria dos quadros. S. MALINA, S. O último secretário. Brasília: Fundação Astrojildo Pereira, 2002; e CUNHA, Paulo Ribeiro da. Aconteceu longe demais: a luta pela terra dos posseiros em Formoso e Trombas e a Revolução Brasileira (1950-1964). São Paulo: Editora da Unesp, 2007.

29 A conspiração civil-militar em São Paulo está detalhada em MOURÃO FILHO, General Olympio. Memórias: a verdade de um revolucionário. Porto Alegre: Editora L + PM, 1978, p. 169-288; SAMPAIO, Regina. Adhemar de Barros e o PSP. São Paulo: Global Editora e Distribuidora Ltda., 1982, p. 103-105; e DREIFUSS, René Armand. 1964: a conquista do estado, ação política, poder e golpe de classe. $3^{\mathrm{a}}$ ed. Petrópolis: Editora Vozes, 1981, p. 376-396. Sobre Ribeirão Preto, vide Em 64, uma paralisação indesejável. Jornal de Ribeirão, p. 4, 21-27 de agosto de 1988; e Diário da Manhã. DN, p. 1, 31 de maio de 1964. 
verdade. Quem controlasse o governo federal controlava a SUPRA e os militares e fazendeiros desejavam esse controle. ${ }^{30}$

Como fica demonstrado com a participação central da SRB no golpe, os cafeicultores de São Paulo achavam-se especialmente ameaçados pela intervenção estatal em seus negócios. A ameaça dessa intervenção sempre inspirou as críticas mais exacerbadas ao governo. Mas a gota d'água veio com a criação da SUPRA. Dada a extraordinária independência das agências do Executivo sob a Constituição de 1946, a SUPRA ameaçava desestabilizar o equilíbrio de forças em detrimento do mais tradicional fragmento da classe dominante do Brasil. ${ }^{31}$

Mesmo assim, no final do processo do governo contra a SUPRA, o Superior Tribunal Militar julgou indeferido o caso. De acordo com o tribunal, os funcionários estavam apenas obedecendo às orientações da lei, e não violado a ordem jurídica. ${ }^{32} \mathrm{~A}$ essa altura, no entanto, o estrago estava feito. Os novos governantes compreenderam que, se diferentes resultados eram desejados, então a lei deveria ser modificada e outra equipe montada para executá-la.

Com o governo sob o controle militar, o superintendente da SUPRA João Pinheiro Neto foi substituído pelo coronel Vital Queiroz e, finalmente, encarcerado como um dos 102 inimigos do Estado, de acordo com as determinações do primeiro de uma série de "atos institucionais". Devido às suas conexões com a elite, Pinheiro Neto foi logo libertado. Mas teve de enfrentar três processos, sendo absolvido em um deles, e os demais foram suspensos. No entanto, uma punição foi aplicada: Pinheiro Neto ficou proibido de ter carreira política, jornalística ou acadêmica. A SUPRA também foi desmantelada. Um dos primeiros atos do coronel Queiroz foi rescindir um dos mais famosos decretos da assembleia popular de 13 de março de 1964 , encerrando os planos para desapropriar as faixas de terras em torno das vias de transporte. Em novembro, a SUPRA foi transformada em duas novas agências, o INDA - Instituto Nacional de Desenvolvimento Agrário, e o IBRA - Instituto Brasileiro de Reforma Agrária, nenhum dos quais promovia a sindicalização rural. Sob a nova lei, o ET - Estatuto da Terra, publicado naquele mês, o IBRA e o INDA estimulariam a colonização de terras no interior distante. ${ }^{33}$

30 Sobre a campanha contra a SUPRA, ver BNM 2/144 (AEL); WELCH. Rivalidade e unificação; e CAMARGO, Aspásia de Alcântara. A questão agrária. In: FAUSTO, Boris (org.). História geral da civilização brasileira. O Brasil republicano: sociedade e política. São Paulo: Difel, 1986, p. 121-224.

31 A lavoura paulista repudia o decreto da SUPRA e "reafirma seu pensamento em favor de uma reforma agrária justa e real”. A Rural (São Paulo) vol. 44, n 515, p. 6, abril de 1964. "Venceu-se, em dois dias", escreveu Almeida Prado da SRB, "a batalha militar, que se constituiu a primeira fase da revolução [...] que, agora vitoriosa, tem um completo programa de reivindicações a cumprir", Do editorial assinado. Da Marcha da Família a revolução vendedora. A Rural vol. 44, n517, p. 3, maio de 1964. Outros exemplos claros de como os conspiradores viam-se como revolucionários encontram-se representados nos títulos de suas memórias. Ver, por exemplo, MOURÃO FILHO, Memórias; D’AGUIAR, Hernani. A revolução por dentro. Rio de Janeiro: 1976. Para mais informações sobre as intenções da SRB, vide Pronunciamentos da SRB durante a revolução redentora do país. A Rural, vol. 44, n 517, pp. 28-30 de maio de 1964.

32 O julgamento de mérito do vice-presidente do tribunal militar, Dr. Waldemar Torres da Costa, foi escrito assim: "Considerando que a SUPRA, organização a que serviam os acusados, era uma instituição oficial, criada pelo Governo Federal, em 11-10-62, e que tinha como uma de suas finalidades a criação de sindicatos rurais, destinados a amparar os trabalhadores interioranos; Considerando que os acusados limitavam-se a cumprir ordens emanadas do alto [...]. ACORDAM, à unanimidade, os Ministros do Superior Tribunal Militar, em negar provimento ao apelo do MP, para confirmar a respeitável decisão apelada, pelos seus fundamentos, que são jurídicos, e pela fidelidade à prova dos autos”. Apelação No. 39.067 - Estado de São Paulo. Superior Tribunal Militar, Rio de Janeiro. 2 de junho de 1972. BNM 12/144.

33 BORGES, Tomás Pompeu Acióli. Estatuto da Terra. In: BELOCH, Israel; ABREU, Alzira Alves de (orgs.). Dicionário histórico-biográfico brasileiro, 1930-1983 (doravante citado como DHBB). Rio de Janeiro: Forense-Universitária, 1984, p. 1203-1205; MEDEIROS, Leonilde Sérvolo de; ARAÚJO, Brás José de. Superintendência da Política Agrária (Supra). In: DHBB, p. 3284; KORNIS, Mônica; SOARES, Leda. Pinheiro Neto, João. DHBB, p. 2740; MEDEIROS, Histórias dos movimentos, p. 85-88; IANNI, Octavio. A luta pela terra. Petrópolis: Vozes, 1978. 
Muitos dos sindicatos criados pelos funcionários da SUPRA no primeiro trimestre de 1964 não foram reconhecidos pelos militares e finalmente foram dissolvidos. Todos os funcionários da CONTAG foram julgados subversivos; 23 das 33 federações estaduais foram consideradas "fantasmas" e os seus registros foram apagados do Ministério do Trabalho. Em um ano o regime fechou 2.381 sindicatos de produtores autônomos, pequenos proprietários, trabalhadores agrícolas e rurais pela mesma razão. Em agosto de 1965 apenas 490 sindicatos tinham permissão para atuar. Muitas pessoas envolvidas com essas organizações sindicais consideradas "subversivas" foram presas ou forçadas a esconderem-se ou deixar o país.

Destacados militantes do PCB em São Paulo, como Lyndolpho Silva e Nestor Vera, não foram presos neste período, mas tiveram seus direitos políticos revogados pelo regime. Silva mudou-se para o exterior, mas Vera - entre outros - entrou para a clandestinidade. ${ }^{34}$ Acostumado a viver na clandestinidade, Moraes escondeu-se em uma fazenda de Altinópolis por três meses. As associações de camponeses e os sindicatos que ele havia ajudado a fundar em Pontal, Sertãozinho, Cajuru e Altinópolis foram todos fechados. Mário Bugliani, o presidente do sindicato de Pontal que Moraes havia auxiliado, também escapou de ser preso e escondeuse na distante Ituverava. Assim como muitos militantes, Moraes e Bugliani logo reclamaram como o regime suprimia quase toda forma de ação coletiva. Em 1967, Bugliani uniu forças com outros militantes dissidentes do PCB, como Vanderlei Caixe e Áurea Moretti para fundar a Frente Armada de Libertação Nacional (FALN), um grupo de guerrilheiros que foi fortemente reprimido e desmantelado por um destacamento policial em 1969, com a prisão de Moraes e Bugliani. ${ }^{35}$

Padre Celso e seus companheiros da FAP tiveram destinos significativamente diferentes. Depois do golpe, padre Celso passou o mês de abril escondido numa pousada em Petrópolis, um santuário franciscano. Em maio, ele voltou, relutante, a Ribeirão Preto, onde descobriu, para sua surpresa, que a polícia não tinha ordem de prisão contra ele. Antônio Ribeiro de Andrade, o capitão de polícia, avisou a padre Celso, no entanto, que grupos armados, apoiadores do golpe, podiam estar à sua procura e aconselhava-o a ficar na cúria da arquidiocese por algum tempo. Lembrando, anos depois do evento, que demonstrou na ocasião uma atitude desafiadora, o padre se recusou a ficar longe das ruas e exigiu ser preso ou deixado em paz. Assim, no dia 3 de maio, a polícia prendeu-o e o confinou-o no quartel da brigada, junto com outros perseguidos considerados inimigos do Estado. Padre Celso havia se oposto ao golpe e queria ser tratado como outros opositores e críticos do novo regime. No final, ele foi mais bem tratado do que esperava. Com toda a disciplina conspiratória e liderança militar do golpe, a tomada de poder tinha

34 Estatísticas sobre a repressão aos sindicatos não estão disponíveis. Estes números baseiam-se nos estudos de jornais da época em PEARSON, Neale J. Small Farmer and Rural Worker Pressure Groups in Brazil. Tese (Doutorado). Universidade da Flórida, 1967, p. 258 e DULLES, John W. F. Unrest in Brazil: Political-military Crises, 1953-1964. Austin: University of Texas Press, 1970, p. 222, que tem uma nota de rodapé sobre o fechamento das federações. Transcrição Moraes parte 1, pp. 89-93. SILVA, Lyndolpho. Transcrição da entrevista feita pelo autor, São Paulo. 16 de agosto de 1988. (AEL). PORTELA, José Alves. Transcrição da entrevista feita pelo autor, São Paulo. 23 de agosto de 1988. (AEL). Vide AmConGen, São Paulo para US/ DOS. "The Revolution's Impact on São Paulo Labor." A-8. 10 de julho de 1964. RG 59, LAB 2 BRAZ (1282). DOS/USNA.

35 Sobre a FALN, vide Processo contra a Frente Armada de Libertação Nacional. B:NM 65 (AEL); MORAES, Irineu Luís de. Transcrição da entrevista com Sebastião Geraldo, Ribeirão Preto, 20 de fevereiro de 1989, parte 2, p. 39-49. PIRES, Áurea Moretti. Entrevistada pelo autor, Ribeirão Preto, 11 de junho de 1997; entrevista com Caixe; Anos de Chumbo. Folha de São Paulo, seção de Ribeirão Preto, p. 1-22, 25 de maio de 1997 e GORENDER, Jacob. Combate nas trevas: a esquerda brasileira das ilusões perdidas à luta armada $2^{\mathrm{a}}$ ed. São Paulo: Ática, 1987. 
também suas ineficiências e pontos fracos. "Fiquei muito bem instalado," afirma, descrevendo a prisão militar improvisada. "Foi um mês de confraternização da esquerda, festiva, de Ribeirão Preto". ${ }^{36}$

A festa terminou para padre Celso no dia 4 de junho. Um dos últimos prisioneiros políticos a ser capturado, ele foi também um dos últimos presos liberados. Ao ser liberado, deparou-se com um novo cenário político. O governo de Castello Branco havia restringido severamente todo tipo de atividade política e qualquer pretensão de expandir o movimento camponês ou realizar ações coletivas para além do sistema judiciário da junta de Trabalho encontrava pronta resistência. O padre tentou se ajustar à nova situação, mas sentia-se especialmente frustrado, pois o arcebispo Rossi recusava sua volta à edição do Diário de Notícias.

Padre Angélico Sândalo Bernardino era agora responsável por esse cargo. Restrito às atividades da paróquia de Vila Seixas, em Ribeirão Preto, padre Celso rebelou-se. No dia 26 de junho, o Diário da Manhã publicou seu "Sermão da Montanha". Nesse texto, padre Celso usava habilidosamente as palavras do apóstolo Mateus para condenar o governo militar e todos os que se acomodavam com ele. "Concretamente," concluía o sermão, "no Brasil de hoje, o cristão que se conforma com a atual ordem e com a estrutura social, que não luta por profundas modificações a favor dos menos afortunados, é o cristão que ainda não pode participar do Santo Sacramento" (itálicos no original). Frustrado, padre Celso encontrou maneiras sutis de se expressar e de agir até abandonar a batina em 1967.37

Os militares intimidaram líderes locais da FAP, como Otávio Sampaio de Batatais e Antônio Crispim da Cruz de Cravinhos, mas, no final, permitiram que continuassem a exercer as funções de presidente de seus respectivos sindicatos de trabalhadores rurais. Na verdade, se por um lado os militares destruíram a SUPRA, fechando centenas de sindicatos e forçando os comunistas a buscarem a clandestinidade, por outro não arrancaram totalmente as raízes do movimento camponês. Significativamente, alguns sindicatos locais e federações estaduais continuaram a existir; o ETR não foi abolido, a CONTAG não foi eliminada e a política agrária, inclusive a reforma agrária, foi finalmente transformada em lei na forma do Estatuto da Terra, aprovado pelo regime em novembro de $1964 .{ }^{38}$

Nas recordações de Crispim a respeito do golpe, a legitimidade fundamental do movimento sindical merece destaque. No dia $1^{\circ}$ de abril, a polícia chegou a sua casa por meio da orientação de seu patrão, o proprietário da Fazenda São José de Colônia Preta. Como sua casa servia de escritório do Sindicato, a polícia revirou-a, recolhendo papéis e quebrando os móveis, em busca de documentos escondidos, armas e explosivos. Eles levaram Crispim à delegacia de Ribeirão Preto, onde diversos agentes do DEOPS o interrogaram. Para cada acusação, ele protestava não ter feito nada de ilegal. O fazendeiro que o tinha denunciado é que havia violado a lei, argumentou, ao maltratar seus empregados, pagando mal e "até proibindo o padre de entrar na fazenda pra socorrer uma família lá que estava passando fome". Nas memórias de Crispim, essa acusação transformou a polícia de inquisidores em simpatizantes. "O capitão do exército pegou e perguntou se

36 Transcrição Syllos. p. 75-76.

37 Sobre o jornal da Igreja, vide Diário de Notícias comemora 37 anos, sob a direção do arcebispo de Ribeirão Preto. DN. p. $4,1^{\circ}$ de julho de 1964 . Sobre o sermão de padre Celso, vide Padre Celso transcrição de Syllos. Crônica religiosa; Momento de Deus; Confusão de revisão. DN. 26 de junho de 1964, p. 2. No início de 1998, o ex-padre Celso foi morto em um acidente de automóvel no Brasil.

38 BRUNO, Regina. O Estatuto da Terra: entre a conciliação e o confronto. Estudos sociedade e agricultura. $\mathrm{n}^{\circ}$ 5, p. 5-31, 1995 . 
era verdade tudo que eu estava dizendo". Segundo Crispim, o policial "pegou e disse: infelizmente é verdade". Aparentemente, a polícia considerou as acusações de Crispim emocionantes e legítimas, porque ele foi liberado e deixado no controle do sindicato do município de Cravinhos. ${ }^{39}$

Essa anedota abre uma janela para que possamos observar as razões que levaram os camponeses a não se rebelaram para defender a administração de João Goulart ou para rejeitar o regime militar. Por um lado, a repressão foi seletiva, permitindo que militantes como Crispim e Sampaio voltassem a seus afazeres, enquanto endurecia com outros considerados radicais e figurões, como João Pinheiro Neto e Lyndolpho Silva. Aparentemente, os militares estavam em busca de uns poucos e seletos líderes, não de todo o movimento. Por outro lado, os militares coordenaram uma campanha eficaz, confundindo, dividindo e surpreendendo seus inimigos populares. Os golpistas agiram tão rapidamente que Moraes não teve tempo de organizar manifestações de protesto, algo que estava acostumado a fazer em tempo recorde. ${ }^{40}$

É difícil dizer como os camponeses teriam reagido a tal chamado. A conquista de direitos sindicais ainda era muito nova e, apesar das dificuldades por quê os camponeses passavam, ainda não havia segurança de que a estrutura sindical garantiria melhoramentos. Pode ser que o presidente Goulart tenha facilitado a criação da estrutura organizativa dos camponeses, mas isso trouxe resultados ambíguos, e os trabalhadores não podem ser responsabilizados por sua ambivalência com relação ao governo. As leis reconheceram os sindicatos, mas que poderes tinham estes para ajudar os trabalhadores quando eram demitidos? Os processos trabalhistas eram apenas uma solução parcial e os sindicatos pouco potentes para proteger os camponeses do poder arbitrário dos fazendeiros. Com aprovação do ETR, Goulart dizia que queria romper os antigos laços entre patrão e cliente, presentes na sociedade rural tradicional, mas, em março de 1964, seus sindicatos ofereciam pouca coisa para substituir essas relações mais confiáveis, ainda que abusivas. ${ }^{41}$ Muitos sindicatos nem tinham iniciado suas atividades quando a ofensiva militar começou.

Talvez não fossem sindicatos "fantasmas", como os classificaram os militares, mas, no momento de disputar o controle da CONTAG, a base certamente foi ignorada. A ênfase foi deslocada, de anos de luta de base clandestina para uma estratégia de juntar sindicatos de qualquer jeito, com o objetivo de ter o maior número de delegados no congresso de fundação da CONTAG. Quando João Goulart caiu três meses depois, o edifício construído pelo PCB foi derrubado com ele, deixando um pequeno suprimento de sindicatos bem fundados e outros que conformaram com a nova situação. Talvez os mais fortes dentre eles fossem os que se abstiveram da disputa envolvendo a CONTAG. É o caso dos sindicatos da FAP na região de Alta Mogiana.

Se por um lado Crispim e Sampaio achavam que os militares permitiram seu retorno à atividade devido ao bom trabalho que estavam realizando, fica claro que cada lado tinha ideias diferentes sobre a tarefa dos líderes dos camponeses e dos

39 Transcrição Crispim, p. 15-20.

40 WELCH, Cliff; GERALDO, Sebastião. Lutas camponesas no interior paulista: memórias de Irineu Luís de Moraes. São Paulo: Editora Paz e Terra, 1992.

41 Este tópico é amplamente elaborado em WELCH, Clifford Andrew. Os com-terra e sem-terra de São Paulo: retratos de uma relação em transição (1945-1996). In: FERNANDES, Bernardo Mançano; MEDEIROS, Leonilde Sérvolo; PAULILO, Maria Ignes (orgs.). Lutas camponesas contemporâneas: condições, dilemas e conquistas. São Paulo: EDUNESP, 2009. 
sindicatos. Crispim e Sampaio queriam ajudar os trabalhadores a melhorar suas vidas, tarefa a que se dedicaram. Mas o regime militar gradualmente estabeleceu uma política cuja prioridade era desenvolver meios eficazes e racionais para explorar os recursos do Brasil, tanto humanos quanto naturais. Do ponto de vista do novo governo, o movimento sindical dos trabalhadores rurais poderia ajudar com de forma eficiente, contendo greves, canalizando reclamações pelos tribunais, treinando trabalhadores no manuseio de maquinário e disponibilizando serviços locais que aliviassem alguns dos abusos decorrentes da transição de um setor agrícola dependente de trabalho manual para um dependente de energia mecanizada.

Em fevereiro de 1965, o ministro do Trabalho, Arnaldo Sussekind, um informante de longa data dos adidos trabalhistas dos Estados Unidos, lançou uma reformulação do ETR eliminando as cinco categorias de atividade profissional rural estabelecidas anteriormente. Isso forçou trabalhadores com diferentes problemas e perspectivas a se unirem em um único sindicato por município, pondo os camponeses uns contra os outros e causando incontáveis problemas internos para o movimento. Crispim e Sampaio continuaram fiéis às suas visões de deveres de um líder sindical, mantendo-se dentro do sistema para poder modificá-lo. ${ }^{42}$

O mesmo não se pode dizer de José Rotta, rival maior do padre Celso. Ele se tornou o líder sindical favorito dos militares. Com todos os seus diretores foragidos, a direção da CONTAG lhe foi entregue e Rotta continuou a receber treinamento e financiamento dos Estados Unidos. Em abril de 1965, o Ministro Sussekind permitiu que Rotta planejasse a sua transição de diretor interino indicado a presidente eleito da CONTAG. O pesquisador-observador Neale Pearson alega que mesmo com a participação de apenas 11 federações estaduais reconhecidas, Rotta assegurouse de que os delegados das federações em que não confiava não participariam, informando-os do encontro quando já era tarde demais.

Pormeio dessaintriga, Rotta excluiuas federações católicas maisprogressivas, as dos estados do Rio Grande do Sul, Minas Gerais, Bahia e Ceará, comprando-se assim mais dois anos de presidência. Sob seu reinado, o movimento camponês se fragmentou. Os líderes dos sindicatos locais se sentiam tão desgostosos com a confederação que romperam seus laços com ela, até que se lançou uma campanha para tirar Rotta da presidência. A antiga frente agrária de padre Celso, Crispim e Sampaio reuniu-se e, juntando-se a outras forças progressivas do Rio Grande do Sul e de Pernambuco, desafiou a liderança de Rotta. Na eleição de 1967, Rotta foi derrotado por uma chapa liderada pelo presidente da federação estadual de Pernambuco, José Francisco da Silva. A partir de 1968, a CONTAG cresceu dramaticamente em força e a estrutura de sindicatos e federações passou a fazer mais sentido para seus membros nos anos 1970.43

O campesinato precisava de uma estrutura de apoio depois da tomada de poder pelos militares. As condições miseráveis com altas taxas de desemprego atingiram um número cada vez maior de camponeses, pois cada vez mais fazendeiros se aproveitavam das leis e do excesso de mão de obra para explorar

42 Transcrições Syllos e Crispim. MEDEIROS. História dos movimentos, p. 92-95.

43 MEDEIROS. História dos movimentos, p. 88-95; PEARSON. Small Farmer and Rural Worker, p. 271-73; AmEmbassy, Rio de Janeiro, para US/DOS. Rural Worker Reaction to Alliance for Progress Program. A-370. 20 de outubro de 1964. RG 59. LAB 10 BRAZ (1283); e AmEmbassy, Rio de Janeiro, para US/DOS. Labor Developments since New Regime Installed. A-295. 25 de setembro de 1964. RG 59. LAB 2 BRAZ (1282), ambos DOS/USNA; e Transcrição Syllos, p. 65-66. As federações que colaboravam com Rotta em 1965 eram aquelas de Pernambuco, Rio de Janeiro, São Paulo, Paraíba, Sergipe, Rio Grande do Norte e Paraná. Depois da sua queda, Rotta reaparece como presidente do sindicato rural de Capivari, São Paulo. 
mais os camponeses. Entre os fazendeiros e usineiros de São Paulo, tornou-se mais eficaz e econômico demitir trabalhadores residentes e expulsar suas famílias, contratando-os de volta como "boias-frias" em trabalho esporádico ou sazonal. Em Pernambuco, também, a condição de morador de engenho quase deixou de existir, sendo preferida a contratação de "clandestinos." Consequentemente, milhões de camponeses mudaram-se para as cidades, inundando os mercados de trabalho dos setores comercial e de serviços. Essas condições permitiram que algumas famílias progredissem, ganhando acesso a serviços urbanos, tais como escolas para seus filhos. Para outras famílias, no entanto, a mudança para a cidade levou à posterior migração para a região amazônica, ainda não totalmente colonizada. Para a maioria, o emprego urbano e rural em condições irregulares não permitia que obtivessem renda superior à necessária para a mais básica sobrevivência. Os combativos líderes sindicais, como Sampaio, continuaram a fazer tudo o que podiam com os recursos à sua disposição, de forma a fornecer aos trabalhadores serviços jurídicos e médicos, aproveitando tudo que for possível da sindicalização rural ao longo dos anos da Ditadura. ${ }^{44}$

\section{Conclusão}

O artigo se divide em dois tipos de abordagem para destacar o estado atual da História Social do Campo. Depois de uma breve introdução do tópico e sua importância para a história contemporânea do Brasil, relata parte da experiência dos historiadores que participaram dos grupos de trabalho dedicados a reconstruir a "verdade" sobre as violações de direitos humanos sofridas pelos camponeses em 1946 e 1988. Num contexto politico, de recursos limitados e sob a pressão de produzir relatórios, a equipe foi orientada a gerar fichas de "casos emblemáticos de violações graves." Sem referência para determinar o que seria um caso emblemático ou como medir uma violação grave, resolveu-se levantar todos os dados disponíveis para o estado de São Paulo com o objetivo de definir tipos de violações e sistematizar as estatísticas em representações gráficas. Como resultado, foram identificados certos padrões de violação, inclusive a prevalência de violações trabalhistas e de graves casos de privação. Mais, em certas regiões as violações de todos os tipos eram piores e em certos períodos, as violações eram mais intensas. Os resultados apresentaram um desafio para a tendência das comissões da verdade de enfatizar casos emblemáticos de assassinato de indivíduos.

Na última parte do artigo, a narrativa analítica da experiência do golpe de 1964 no movimento camponês em Ribeirão Preto permitiu explorar em detalhe um "caso emblemático" e uma "verdade" sobre a história social do campo no período. Encontramos nela exemplos de todos os tipos de violação: violência contra pessoas, violações dos direitos de liberdade, das leis trabalhistas e interferência na vida privada dos camponeses. Alguns dias de eventos dramáticos geraram complicações para as pessoas que duraram anos até se concretizaram. Por exemplo, o militante Moraes, assim como o cortador Bugliani, entrou para a luta armada. Ambos foram

44 Sobre a história recente do trabalhismo rural no Brasil, vide, por exemplo, D’INCAO, Maria Conceição. O 'Bóia-Fria': acumulação e miséria. $8^{a}$ edição, Petrópolis: Vozes, 1975; SIGUAD, Lygia. Os clandestinos e os direitos: estudo sobre trabalhadores da cana-de-açúcar de Pernambuco. São Paulo: Editora Duas Cidades, 1979; PALMEIRA, Moacir. The Aftermath of Peasant Mobilization: Rural Conflict in the Brazilian Northeast Since 1964. In: AGUIAR, Neuma (org.). The Structure of Brazilian Development. New Brunswick: Transaction Books. 1979, p. 71-97. MAYBURY-LEWIS. The Politics of the Possible. 
presos e torturados anos depois de março de 1964. Um movimento social que demorou décadas para ser construído foi brutalmente arrancado das mãos de seus protagonistas e entregado a estranhos. Organizações construídas para oferecer um pouco de proteção e ajuda mútua foram desmanteladas e convertidas em instrumentos de pacificação. O exemplo mostrou a partir do uso de uma diversidade de fontes, levantadas durante anos, a complexidade de um "caso emblemático" da repressão ao movimento camponês após o golpe militar-civil.

Recebido em: 20/04/2014

Aprovado em: 28/05/2014 